\title{
Lipid transport in kwashiorkor
}

\author{
By H. FLORES, NELLY PAK, A. MACCIONI AND F. MONCKEBERG \\ Laboratorio de Investigaciones Pediatricas, Facultad de Medicina, \\ Universidad de Chile, Hospital M. Arriaran, Casilla 5370, Santiago, Chile
}

(Received 9 February 1970-Accepted 7 Fune 1970)

\begin{abstract}
I. In an attempt to elucidate the pathogenic mechanism of the fatty liver of kwashiorkor some aspects of lipid metabolism were studied in ten patients with kwashiorkor and nine with marasmus, so classified according to the clinical and laboratory findings.

2. Plasma lipid levels, especially those of triglycerides, were low in patients with kwashiorkor; they showed a marked rise very early during treatment.

3. The changes in the plasma lipid levels occurred mainly in the serum lipoprotein fraction of density $<\mathbf{r} \cdot 063$. The elevation of plasma lipid levels during treatment coincided with a loss of liver lipids and a marked rise in serum protein concentration.

4. The findings support the suggestion that the primary mechanism in the production of the fatty liver of kwashiorkor is an impairment in the synthesis of lipoprotein of very low density, probably due to the rate-limiting synthesis of its protein moiety.

5. In patients with marasmus no modifications in lipid metabolism were detected by the methods used.
\end{abstract}

The fatty liver usually observed in kwashiorkor has been consistently found to be associated with low concentrations of plasma lipids, especially triglycerides, which rise above normal during treatment (Schwartz \& Dean, 1957; Macdonald, Hansen \& Bronte-Stewart, 1963; Lewis, Hansen, Wittman, Krut \& Stewart, 1964; Mönckeberg, I966; Flores, Pak, Maccioni \& Mönckeberg, I967; Truswell, Hansen, Watson \& Wannenburg, 1969). This has been interpreted as suggestive of a block in the release of hepatic triglycerides (Schwartz \& Dean, r957; Mönckeberg, 1966; Flores et al. ı 967 ; 'Truswell et al. 1969) which constitute the principal lipid fraction accumulated in the liver (Iturra, 1947; Macdonald, 1960). It has been assumed that the excess liver fat is the source of the rise in plasma triglycerides during treatment (Schwartz \& Dean, I957; Mönckeberg, I966), but no direct evidence for this hypothesis has been provided.

The present study was undertaken to correlate the changes in the concentration of lipids in the unfractionated serum and in the high-density and low-density lipoproteins with the clearing of the liver fat during recovery from kwashiorkor. The results obtained support the hypothesis of a block in the release of liver triglycerides as the primary cause of the fatty liver in kwashiorkor.

\section{EXPERIMENTAL}

Ten patients with kwashiorkor, aged $12-27$ months, and nine patients with marasmus, aged 4-I4 months, all of whom showed a marked growth retardation, were admitted to our metabolic ward. The children selected for these groups were carefully chosen from among many other malnourished children whose signs and symptoms overlapped. All the patients with kwashiorkor presented the following signs: hypo- 
proteinaemia, anaemia, skin and mucosal lesions, oedema and enlargement of the liver due to fatty infiltration as determined by histochemical analysis of biopsy specimens. The children with marasmus presented with apathy, a severe weight deficit of more than $40 \%$ below the ideal weight for age (Nelson, 1959) and absence of subcutaneous fat. They did not have oedema, skin lesions or enlargement of the liver. Only dietary treatment was given, providing about $\mathrm{I} 80 \mathrm{kcal} / \mathrm{kg}$ per $\mathrm{d}$ and $3 \mathrm{~g}$ protein $/ \mathrm{kg}$ per $\mathrm{d}$ as milk protein.

On admission and at different periods during recovery, blood samples were taken, always after an overnight fast, from the patients with kwashiorkor. The blood samples were centrifuged immediately and the serums collected. Control blood samples were obtained from a group of thirteen healthy children aged I4-2I months.

Liver biopsies in patients with kwashiorkor were performed during the first $5 \mathrm{~d}$ after admission and repeated between the 8 th and the 15 th days of treatment. In patients with marasmus blood and liver samples were taken only on admission.

Parental consent was always obtained before performing the liver biopsies and all necessary precautions were taken; this procedure involves negligible risk (Stuart, Bras, Patrick \& Waterlow, I958). The investigation was considered to be not only of academic but of considerable practical interest in the treatment of kwashiorkor; in fact it is not known whether any special attention should be paid to the fatty infiltration of the liver during treatment, which usually consists only of providing adequate diets.

Plasma free fatty acids (FFA) were measured by the method of Goss \& Allen (Ig66). Serum triglycerides were measured by the method of Carlson (1963). Lipid phosphorous was determined as described by Fiske \& Subbarrow (1925). Cholesterol was measured by the method of Abell, Levy, Brodie \& Kendall (1952). Protein was determined by the biuret reaction (Gornall, Bardawill \& David, I949).

The different serum protein fractions were estimated by paper electrophoresis.

Two lipoprotein fractions were separated by ultracentrifugation at density $(d)=\mathrm{I} \cdot 063$ (Havel, Eder \& Bragdon, 1955) in some of the samples. The different lipid fractions were determined in each fraction by direct analysis; the recovery in individual samples varied between 93 and $105 \%$ as calculated from the value obtained for total serum.

The liver biopsy specimens were sliced and desiccated over $\mathrm{P}_{2} \mathrm{O}_{5}$; total lipids were then extracted with 20 volumes of chloroform-methanol, 2: I. After partition dialysis by the method of Folch, Lees \& Sloane-Stanley (1954) chloroform-methanol was added to a known volume and portions were taken for the determination of total lipids by the method of Bragdon (195I). Total liver lipid was expressed as mg palmitic acid per mg liver nitrogen (Johnson, I94I) in order to avoid any misinterpretation of results due to differences in the water content of the liver samples.

The fatty infiltration was also evaluated by staining with Sudan III and graded microscopically. Both the chemical and histochemical analyses were always done in the fresh samples because some lipolysis seemed to occur upon storage even at $-18^{\circ}$.

Reagents were all analytical grade. The cholesterol, palmitic acid and tripalmitin used as standards were purchased from the Sigma Chemical Co. (St Louis, Mo., USA). 
RESULTS

On admission, serum lipids, especially triglycerides, were low in patients with kwashiorkor (Table $\mathrm{r}$ ) in keeping with the observations of Schwartz \& Dean (I957), Lewis et al. (1964) and Truswell et al. (1969). These low values were accounted for

Table I. Lipids of total serum and of high-density and low-density lipoproteins in infantile malnutrition

(Mean values with their standard errors; figures in parentheses are numbers of patients)

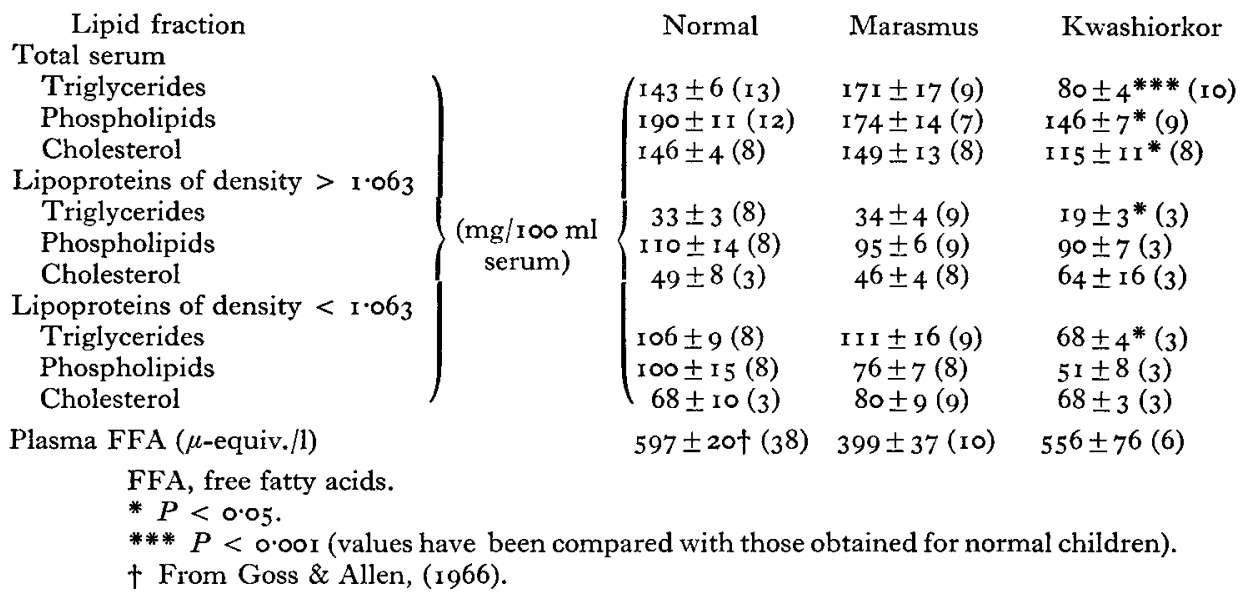

Table 2. Plasma free fatty acids (FFA), liver lipids and serum proteins in kwashiorkor (Mean values with their standard errors; figures in parentheses are the numbers of patients)

\begin{tabular}{|c|c|c|}
\hline & At admission & After $8-\mathrm{I} 2 \mathrm{~d}$ treatment \\
\hline Plasma FFA ( $\mu$-equiv. $/ 1)$ & $556 \pm 76(6)$ & $426 \pm 69(5)$ \\
\hline Liver lipids (mg palmitic acid/mg N) & $10.4 I \pm 0.8 I(4)$ & $5.41 \pm 0.76 * * *(5)$ \\
\hline Total serum protein $(\mathrm{g} / 100 \mathrm{ml})$ & $4.15 \pm 0.26(7)$ & $6.00 \pm 0.63 *(6)$ \\
\hline Serum $\beta$-globulins $(\mathrm{g} / 100 \mathrm{ml})$ & $0.37 \pm 0.09(4)$ & $0.84 \pm 0.04 *(4)$ \\
\hline Serum albumin $(\mathrm{g} / \mathrm{1} 00 \mathrm{ml})$ & $2 \cdot 38 \pm 0.47(4)$ & $4.05 \pm 0.56(4)$ \\
\hline Serum $\alpha_{1^{-}}$and $\alpha_{2}$-globulins $(\mathrm{g} / 100 \mathrm{ml})$ & $0.66 \pm 0.10(4)$ & $0.61 \pm 0.05(4)$ \\
\hline$* P<0.02$ & *** $P<0.001$ & \\
\hline
\end{tabular}

mainly by the $d<\mathrm{I} \cdot 06_{3}$ lipoprotein fraction. Patients with marasmus presented values within normal limits in all the lipid fractions studied. Serum FFA were within the normal range in both patients with marasmus and those with kwashiorkor (Table $\mathbf{r}$ ).

Histochemical analysis of the liver samples taken on admission confirmed the presence of fatty liver in the patients with kwashiorkor and its absence in those with marasmus. Chemical analysis of some of the samples demonstrated a high level of liver lipids in the patients with kwashiorkor (Table 2), equivalent to an average of $25 \%$ of wet weight.

Plasma proteins were markedly reduced in the patients with kwashiorkor, the greatest reduction being in $\beta$-globulins. It was observed that there was a relationship between low values for $\beta$-globulins and the presence of fatty liver in the malnourished children (Fig. I). 
During treatment of patients with kwashiorkor a sharp rise in serum triglycerides, and to a lesser extent in serum phospholipids and cholesterol, was observed, confirming the early observations of Schwartz \& Dean (1957) (Table 3). These changes occurred mainly in the $d<\mathrm{I} \cdot 06_{3}$ lipoprotein fraction.

There was a good correlation between the concentrations of triglycerides, phospholipids and cholesterol in the $d<\mathrm{I} \cdot 06_{3}$ lipoprotein fraction (Fig. 2).

\section{Table 3. Effect of treatment of patients with kwashiorkor on the lipids} of total serum and of serum lipoproteins

(Mean values with their standard errors; figures in parentheses are the numbers of patients)

$$
\text { Lipid fraction } \quad \begin{array}{llll}
0-2 \mathrm{~d} & 3-5 \mathrm{~d} & 6-8 \mathrm{~d} & 8 \mathrm{~d}
\end{array}
$$

Total serum

Triglycerides

Phospholipids

Cholesterol

Lipoproteins of

density $>\mathrm{I} \cdot 063$

Triglycerides

Phospholipids (mg/roo $\mathrm{ml}$ serum)

Cholesterol

Lipoproteins of

density $<1.063$

Triglycerides

Phospholipids

Cholesterol

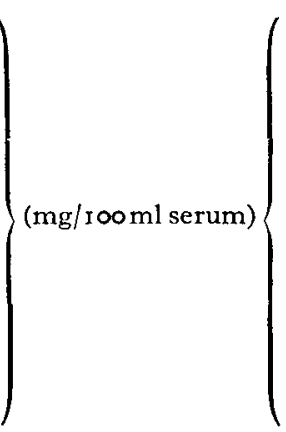

$$
\begin{aligned}
& (80 \pm 4 \text { (10) } 205 \pm x * * *(7) \text { I9I } \pm 7(7) \quad \text { I } 52 \pm \text { I } 5(7) \\
& 146 \pm 6(9) \quad 192 \pm 5 * * *(7) \quad 205 \pm 11(7) \quad 173 \pm 12(6) \\
& \text { II } 5 \pm \text { I2 (8) I3I } \pm 6(7) \quad \text { I4I III (4) } 106 \pm 16(4) \\
& 19 \pm 3(3) \quad 3 x \pm 7(5) \quad 46 \pm 12(5) \quad 34 \pm 6(7) \\
& 90 \pm 7(3) \quad 76 \pm 9(3) \quad \mathrm{r} 8 \pm 9^{* * *}(3) \quad 109 \pm 16(7) \\
& 64 \pm 16(3) \quad 29 \pm 4(3) \quad 72 \pm 11(3) \quad 49 \pm 12(7) \\
& 68 \pm 4(3) \quad \text { I } 54 \pm \mathrm{I} 7 * * *(4) \quad 122 \pm 8(4) \quad \text { I04 } \pm 9(7) \\
& 51 \pm 8(3) \quad 121 \pm 18 *(3) \quad 124 \pm 18(3) \quad 94 \pm 19(6) \\
& \begin{array}{llll}
68 \pm 3(3) & 88 \pm 7(3) & 78 \pm 8(3) & 67 \pm 4(6)
\end{array}
\end{aligned}
$$

Values have been compared to those obtained at o-2 $\mathrm{d}$ (admission). Only the earliest significant differences are quoted.

* $P<0.05$.

*** $P<0.001$.

After 8-I2 d of treatment a reduction of up to $50 \%$ of the initial liver lipid content was observed in patients with kwashiorkor (Table 2). In these, plasma FFA showed a slight decrease of no statistical significance.

All the serum protein fractions increased in $\mathbf{I}-2$ weeks of treatment but only the rise in $\beta$-globulins was significant in this period (Table 2 ).

\section{DISCUSSION}

The low fasting triglyceride levels in serum (Table I) (Schwartz \& Dean, I957; Lewis et al. 1964; Flores et al. 1967; Truswell et al. 1969) and the high value for liver lipids (Table 2), especially triglycerides (Iturra, 1947; Macdonald, 1960), present a pattern of lipid metabolism similar to that observed in fatty livers induced experimentally by blocking the synthesis of low-density lipoproteins (Robinson \& Seakins, I962) which are responsible for the transport of liver triglycerides to plasma (Fredrickson, Levy \& Lees, 1967).

Thus, a block in the release of hepatic triglycerides to plasma appears to be the primary mechanism in the pathogenesis of the fatty liver of kwashiorkor. This hypothesis, already suggested by Schwartz \& Dean (1957), is supported by our findings, which show that the low levels of plasma lipids observed at admission of patients with kwashiorkor are due mainly to a reduction in the low-density lipoprotein fraction (Table $\mathrm{I}$ ). This fraction also accounted for the increase of serum lipids observed during 
Vol. 24

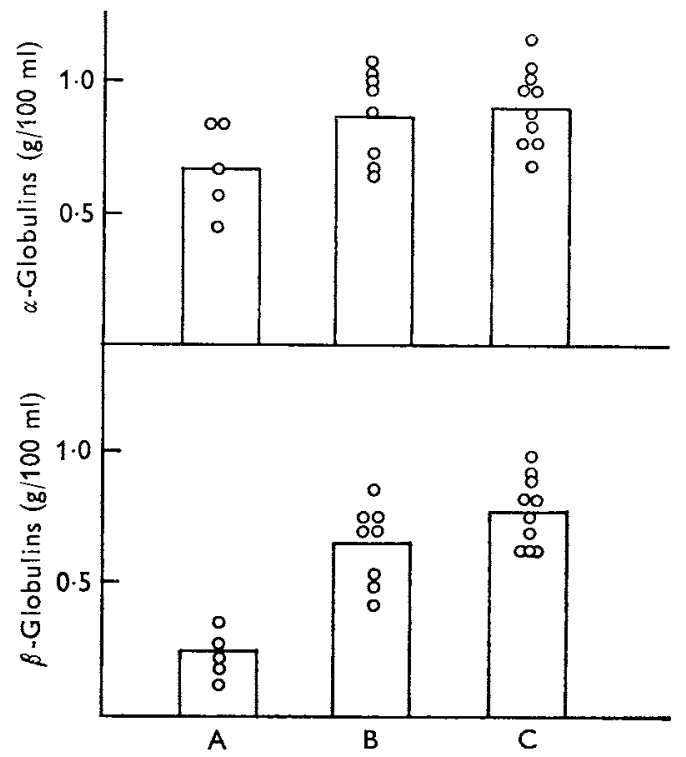

Fig. I. Relationship between serum $\beta$-globulins and fatty liver in malnourished children. A, children with fatty liver (kwashiorkor); B, children without fatty liver (marasmus); $C$, normal children.

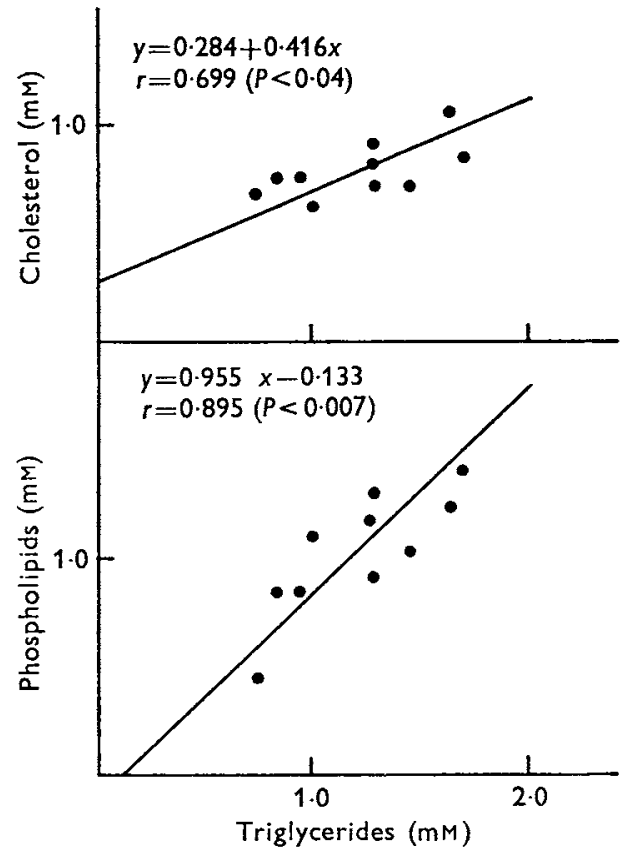

Fig. 2. Correlation between the concentration of triglycerides and phospholipids and between triglycerides and cholesterol in serum low-density lipoproteins (density $<1 \cdot 063$ ) of children recovering from kwashiorkor. 
treatment (Table 3), which is in agreement with the finding by Truswell et al. (1969) of the appearance of a pre- $\beta$-lipoprotein band in the electrophoresis of serum from patients recovering from kwashiorkor. Suggestive evidence that the liver is the source of this increase is provided by the observation that it was concomitant with reduction in liver fat (Table 2).

An important observation derived from this study is the correlation found between the levels of triglycerides, phospholipids and cholesterol in the $d<\mathrm{r} \cdot 06_{3}$ lipoprotein fraction of serum from the patients with fatty liver (Fig. 2). Heimberg, Weinstein, Dishmon \& Fried (1965) and later Weinstein, Dishmon \& Heimberg (1966) have observed such a correlation in the release of lipids from perfused rat livers. They deduced from this that the $d<\mathrm{r} .020$ lipoprotein, the subject of their study, may correspond to a well-defined chemical entity whose components occur in fixed proportions. Our findings suggest that this is also applicable to the human low-density lipoproteins.

It has been postulated that the synthesis of low-density lipoproteins may be inhibited and lead to fatty liver, by blocking the synthesis of any of their components (Heimberg et al. 1965; Weinstein et al. 1966). Thus, fatty livers have been caused experimentally by the administration of inhibitors of protein synthesis (Robinson \& Seakins, 1962; Heimberg et al. 1965) or by diets devoid of choline which prevent phospholipid synthesis (Lombardi, Ugazio \& Raick, 1966).

No evidence of impaired phospholipid synthesis has been found in kwashiorkor (Truswell et al. 1969). Chatterjee \& Mukherjee (1968) have reported low values for total phospholipids as a percentage of liver weight in kwashiorkor, but their results can be recalculated to show no reduction if expressed on a fat-free weight basis. The concentration of total phospholipids in plasma is only slightly reduced (Schwartz \& Dean, 1957; Lewis et al. 1964; Truswell et al. 1969) (Table I) and shows only a secondary rise during treatment (Schwartz \& Dean, I957; Lewis et al. 1964) (Table 3). On the other hand, the low protein intake, part of the aetiology of kwashiorkor (Waterlow, Cravioto \& Stephen, I960; Scrimshaw \& Behar, 1965; Mönckeberg, 1966), makes it likely that the defect lies in the synthesis of the protein moiety of low-density lipoproteins. In favour of this hypothesis, already suggested by us (Mönckeberg, I 966 ; Flores et al. 1967; Mönckeberg, 1968) and by Truswell et al. (1969), is the finding of a close relationship between very low levels of plasma $\beta$-globulins and the presence of fatty liver in malnourished children (Fig. I). In fact, Lees (1967) has found that the circulating apoprotein of low-density lipoproteins (Roheim, Miller \& Eder, 1965) is a $\beta$-globulin. Animal experiments have shown that this circulating apoprotein is the limiting factor for the release of liver triglycerides to plasma in protein-depleted rats (Flores, Sierralta \& Mönckeberg, 1970).

Our finding of normal plasma levels of FFA in patients with kwashiorkor conflicts with observations of other workers (Fletcher, 1966; Hadden, 1967; Lewis et al. 1964; Lewis, Wittmann, Krut, Hansen \& Brock, I966; Rao \& Prasad, 1966) who found high levels, leading to the conclusion that increased transport of fatty acids from depots to liver may play a part in causing fatty liver in kwashiorkor (Lewis et al. 1964; 1966). While the absence of diarrhoea and vomiting in our patients could explain 
the discrepancy, our finding suggests that high concentrations of plasma FFA are not necessarily associated with kwashiorkor, and their role, if any, in the fatty infiltration of the liver, is undoubtedly limited. In this context it seems important to mention the observation of Lewis et al. (1964) that, though the increase of serum triglycerides was dependent on protein repletion, the lowering of plasma FFA was not. Moreover, the high concentrations of plasma FFA are also observed in patients with marasmus, in whom fatty liver does not develop (Lewis et al. 1964, 1966).

The patients with marasmus in this study all had normal concentrations of plasma lipids as well as of plasma proteins, including $\beta$-globulins; this provides further evidence that the changes discussed above are specifically associated with the fatty infiltration of the liver.

This investigation was supported by NIH grant AM 04226-07. The authors are indebted to Professor J. C. Waterlow for advice in the preparation of the manuscript.

\section{REFERENCES}

Abell, L. L., Levy, B. B., Brodie, B. B. \& Kendall, F. E. (1952). F. biol. Chem. 195, 357.

Bragdon, J. H. (195I). F. biol. Chem. r9o, 5 I3.

Carlson, L. A. (1963). $\mathscr{~}$. Atheroscler. Res. 3, 334.

Chatterjee, K. K. \& Mukherjee, K. L. (1968). Br. F. Nutr. 22, 145.

Fiske, C. H. \& Subbarrow, Y. (1925). F. biol. Chem. 66, 375.

Fletcher, K. (1966). Am. F. clin. Nutr. 19, 170.

Flores, H., Pak, N., Maccioni, A. \& Mönckeberg, F. (1967). Abstracts of the 37th Annual Meeting of the Society for Pediatric Research, April 1967, Atlantic City, USA, p. I43.

Flores, H., Sierralta, W. \& Mönckeberg, F. (1970). f. Nutr. 100, 375.

Folch, J., Lees, M. \& Sloane-Stanley, G. H. (1954). Fedn Proc. Fedn Am. Socs exp. Biol. 13, 209.

Fredrickson, D. S., Levy, R. I. \& Lees, R. S. (I967). New Engl. F. Med. 276, 215.

Gornall, A. G., Bardawill, C. J. \& David, M. M. (1949). F. biol. Chem. I77, 75 I.

Goss, J. E. \& Allen, L. (1966). Clin. Chem. 13, 36.

Hadden, D. R. (1967). Lancet ii, 589 .

Havel, R. J., Eder, H. A. \& Bragdon, J. H. (r955). F. clin. Invest. 34, 1345.

Heimberg, M., Weinstein, I., Dishmon, G. \& Fried, M. (1965). Am. F. Physiol. 209 , 1053.

Iturra, T. S. (I947). Estudio de los lipidos hepáticos en lactantes distróficos. MD Thesis, Escuela de Medicina, Universidad de Chile.

Johnson, M. J. (I941). F. biol. Chem. 137, 575.

Lees, R. S. (1967). F. Lipid Res. 8, 396.

Lewis, B., Hansen, J. D. L., Wittman, W., Krut, L. H. \& Stewart, F. (1964). Am. F. clin. Nutr. I5, I6 I. Lewis, B., Wittman, W., Krut, L. H., Hansen, J. D. L. \& Brock, J. F. (1966). Clin. Sci. 30, 37 I.

Lombardi, B., Ugazio, G. \& Raick, A. N. (1966). Am. Y. Physiol. 21o, 3 I.

Macdonald, I. (1960). Metabolism 9, 838 .

Macdonald, I., Hansen, J. D. L. \& Bronte-Stewart, B. (1963). Clin. Sci. 24, 55 .

Mönckeberg, F. (1966). Nutrición Bromatologia Toxicologia 5, $3 \mathrm{I}$.

Mönckeberg, F. (I968). In Calorie Deficiencies and Protein Deficiencies p. 9 I [R. A. McCance and Elsie M. Widdowson, editors]. London: J. and A. Churchill Ltd.

Nelson, W. E. (1959). Textbook of Pediatrics 7 th ed., p. 50. Philadelphia and London: W. B. Saunders Co.

Rao, K. S. J. \& Prasad, P. S. K. (1966). Am. F. clin. Nutr. 19, 205.

Robinson, D. S. \& Seakins, A. (1962). Biochim. biophys. Acta 62, 163.

Roheim, P. S., Miller, L. \& Eder, H. A. (1965). F. biol. Chem. 240, 2994.

Schwartz, R. \& Dean, R. F. A. (1957). F. trop. Pediat. 3, 23.

Scrimshaw, N. S. \& Behar, M. (1965). New Engl. 7. Med. 272, 137.

Stuart, K. L., Bras, G., Patrick, S. J. \& Waterlow, J. C. (1958). A.M.A. Arch. Int. Med. тог, 67.

Truswell, S. A., Hansen, J. D. L., Watson, C. E. \& Wannenburg, P. (1969). Am. F. clin. Nutr. $22,568$.

Waterlow, J. C., Cravioto, J. \& Stephen, J. M. L. (1960). Adv. Protein Chem. I5, I31.

Weinstein, I., Dishmon, G. \& Heimberg, M. (1966). Biochem. Pharmac. 15, 85 I. 